\title{
Second-Sphere Effects on Methane Hydroxylation in Cu-Zeolites
}

\author{
Benjamin E. R. Snyder, ${ }^{\dagger}$ Pieter Vanelderen, ${ }^{\dagger}$ Robert A. Schoonheydt, ${ }^{* \neq}$ Bert F. Sels, ${ }^{*,+}$
} and Edward I. Solomon $* \dagger \oplus$

\author{
${ }^{\dagger}$ Department of Chemistry, Stanford University, Stanford, California 94305, United States \\ ${ }^{\ddagger}$ Department of Microbial and Molecular Systems, Centre for Surface Chemistry and Catalysis, KU Leuven - University of Leuven, \\ Celestijnenlaan 200F, B-3001 Leuven, Belgium
}

\section{Supporting Information}

ABSTRACT: Two $\left[\mathrm{Cu}_{2} \mathrm{O}\right]^{2+}$ cores have been identified as the active sites of low temperature methane hydroxylation in the zeolite $\mathrm{Cu}-\mathrm{MOR}$. These cores have similar geometric and electronic structures, yet different reactivity with $\mathrm{CH}_{4}$ : one reacts with a much lower activation enthalpy. In the present study, we couple experimental reactivity and spectroscopy studies to DFT calculations to arrive at structural models of the $\mathrm{Cu}-\mathrm{MOR}$ active sites. We find that the more reactive core is located in a constricted region of the zeolite lattice. This leads to close van der Waals contact between the substrate and the zeolite lattice in the vicinity of the active site. The resulting enthalpy of substrate adsorption drives the subsequent $\mathrm{H}$ atom abstraction step-a manifestation of the "nest" effect seen in hydrocarbon cracking on acid zeolites. This defines a mechanism to tune the reactivity of metal active sites in microporous materials.

\section{INTRODUCTION}

A direct catalytic conversion of methane to methanol would enable more efficient use of our growing natural gas reserves. However, this is a fundamentally challenging reaction due to the inert $104 \mathrm{kcal} / \mathrm{mol} \mathrm{C}-\mathrm{H}$ bond of $\mathrm{CH}_{4}$ and favorable thermodynamics of subsequent oxidation to $\mathrm{CO}_{2}$. Nonetheless, a handful of natural and synthetic systems exist that perform this chemistry at low temperature. In nature, there are the soluble and particulate methane monooxygenases, ${ }^{1}$ which hydroxylate methane catalytically under ambient conditions using atmospheric $\mathrm{O}_{2}$. In heterogeneous catalysis, there are the $\mathrm{Fe}$ - and $\mathrm{Cu}$-zeolites. ${ }^{2}$ The Fe-zeolites contain a mononuclear $\mathrm{S}$ $=2 \mathrm{Fe}(\mathrm{IV})=\mathrm{O}$ reactive intermediate, formed from $\mathrm{N}_{2} \mathrm{O}$, that hydroxylates methane rapidly at room temperature. ${ }^{3,4}$ For the $\mathrm{Cu}$-zeolites, a number of different methane reactive sites have been identified. ${ }^{2,5-7}$ Of these, the most fully characterized are the $[\mathrm{Cu}-\mathrm{O}-\mathrm{Cu}]^{2+}$ cores formed in $\mathrm{O}_{2}$-activated $\mathrm{Cu}-\mathrm{ZSM}-5$ and $\mathrm{Cu}-\mathrm{MOR}$.

$\mathrm{Cu}-\mathrm{ZSM}-5$ contains a single $\left[\mathrm{Cu}_{2} \mathrm{O}\right]^{2+}$ site, while $\mathrm{Cu}-\mathrm{MOR}$ contains two (MOR1 and MOR2). 6 " Experimentally, all three $\left[\mathrm{Cu}_{2} \mathrm{O}\right]^{2+}$ cores have comparable geometric and electronic structures (Table 1). In absorption spectroscopy, they exhibit intense low energy Abs features at ca. $22000 \mathrm{~cm}^{-1}$. Tuning a laser into this $\mathrm{Abs}$ feature resonance enhances the symmetric and antisymmetric stretching modes of the bridging oxo ligand, leading to its assignment as an oxo $\rightarrow \mathrm{Cu}$ (II) ligand to metal charge transfer (LMCT) transition. The low energy and high intensity of this $\mathrm{CT}$ transition reflects the high $\mathrm{Cu} / \mathrm{O}$
Table 1. Experimental Spectroscopic Features of $\left[\mathrm{Cu}_{2} \mathrm{O}\right]^{2+}$ Cores in ZSM-5 and MOR, along with (Apparent) $\mathrm{CH}_{4}$ Activation Parameters ${ }^{a, 6,7}$

$\begin{array}{llll} & \text { ZSM-5 } & \text { MOR1 } & \text { MOR2 } \\ \text { LMCT }\left(\mathrm{cm}^{-1}\right) & 22700 & 21900 & 23100 \\ v_{\text {sym }}\left(\mathrm{cm}^{-1}\right) & 456 & 465 & 450 \\ v_{\text {asym }}\left(\mathrm{cm}^{-1}\right) & 870 & 850 & 870 \\ \mathrm{CH}_{4} \Delta H^{\ddagger}(\mathrm{kcal} / \mathrm{mol}) & 15.7 & 14.7 & 11.1 \\ \mathrm{CH}_{4} \Delta S^{\ddagger}(\mathrm{cal} / \mathrm{mol} \cdot \mathrm{K}) & -35 & -36 & -44\end{array}$

${ }^{a_{T}}$ The oxo $\rightarrow \mathrm{Cu}(\mathrm{II})$ LMCT energies, $\mathrm{Cu}-\mathrm{O}-\mathrm{Cu}$ symmetric and antisymmetric stretching frequencies, and $\mathrm{CH}_{4}$ activation parameters are reported.

covalency of this active site. ${ }^{2,6}$ Past DFT studies of Cu-ZSM-5 showed this leads to FMOs with high oxo $2 \mathrm{p}$ content that are highly activated acceptor orbitals for $\mathrm{H}$ atom abstraction. ${ }^{6}$ This is consistent with experimental reactivity data, which show $\mathrm{Cu}$ ZSM-5 and MOR1 perform $\mathrm{H}$ atom abstraction (HAA) from $\mathrm{CH}_{4}$ with a low activation enthalpy of $\Delta H^{\ddagger}=14.7-15.7 \mathrm{kcal} /$ mol (Table 1). The barrier for MOR2 is even lower, however, at $\Delta H^{\ddagger}=11.1 \mathrm{kcal} / \mathrm{mol}$. This large difference in reactivity cannot be explained by the small differences in the geometric/ electronic structures of these cores from spectroscopy. Instead, based on the more negative activation entropy of MOR2 $\left(\Delta S^{\ddagger}\right.$ $=-44 \mathrm{cal} / \mathrm{mol} \cdot \mathrm{K})$ relative to MOR1 $\left(\Delta S^{\dagger}=-36 \mathrm{cal} / \mathrm{mol} \cdot \mathrm{K}\right)$

Received: May 21, 2018

Published: June 28, 2018 

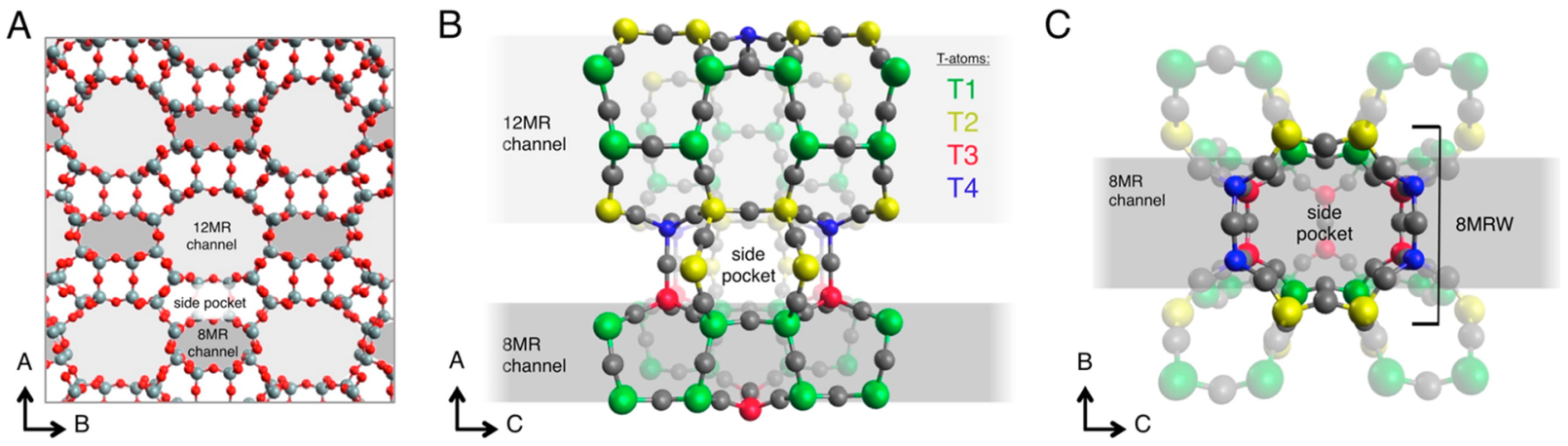

Figure 1. (A) Structure of the MOR lattice, illustrating the one-dimensional pore network consisting of arrays of open $12 \mathrm{MR}$ channels (light gray, 8 $\AA \times 10 \AA$; including van der Waals radius, $5 \AA \times 7 \AA$ ) and constricted 8MR channels (dark gray, $3.5 \AA \times 8 \AA$; including van der Waals radius, $0.5 \AA$ $\times 5 \AA$ ) collinear with the crystal $c$ axis. The side pockets, which connect the $8 \mathrm{MR}$ and $12 \mathrm{MR}$ channels, are colored white. Rotating the lattice by $90^{\circ}$ around the $a$ axis shows the 12MR and $8 \mathrm{MR}$ channels in (B), connected by side pockets. Four types of lattice $\mathrm{T}$ atoms are identified by color (T1, green; T2, yellow; T3, red; T1, blue). ${ }^{8}$ Rotating this structure by $90^{\circ}$ counterclockwise around the $c$ axis shows the void space of the side pocket connecting the $8 \mathrm{MR}$ channel and $12 \mathrm{MR}$ channel, shown in (C). The 8-membered ring windows (8MRW) of the side pocket are highlighted-one exposed to the 12MR channel composed of yellow T2 and blue T4 atoms (yellow and blue, respectively), and one exposed to the $8 \mathrm{MR}$ channel composed of green $\mathrm{T} 1$ and red $\mathrm{T} 3$ atoms.

and Cu-ZSM-5 $\left(\Delta S^{\ddagger}=-35 \mathrm{cal} / \mathrm{mol} \cdot \mathrm{K}\right)$, it was proposed that MOR2 lies in a more constricted region of the MOR latticefor example, the side pocket or 8 -membered ring ( $8 \mathrm{MR}$ ) channel in Figure $1 .^{7}$ Second-sphere atoms in close proximity to the active site could then have some influence on the HAA reaction coordinate. On the other hand, it was proposed that the lattice environment of MOR1 is more open, like Cu-ZSM5; and 8-membered ring windows (8MRW) in the wall of the open 12MR channel (see Figure 1C) were identified as a potential location of MOR1 formation. ${ }^{7}$

This raised the interesting idea that an active site in a constricted location can react with a lower barrier than an active site in a more open location. In the present study, we show that this is, in fact, the case using experimental reactivity data coupled to DFT calculations. We first experimentally define the locations of MOR1 and MOR2 in the MOR lattice using two different steric probe substrates. This information is used to construct a number of $\left[\mathrm{Cu}_{2} \mathrm{O}\right]^{2+}$ computational models that are evaluated against spectroscopic data, leading to structural models of MOR1 and MOR2. The MOR1 and MOR2 models are then used to interrogate the $\mathrm{CH}_{4} \mathrm{HAA}$ reaction, revealing how enhanced reactivity is achieved for a $\left[\mathrm{Cu}_{2} \mathrm{O}\right]^{2+}$ active site in a constricted location. This defines a mechanism to tune the reactivity of metal active sites in microporous materials.

\section{MATERIALS AND METHODS}

2.1. Sample Preparation. Samples of $\mathrm{Cu}-\mathrm{MOR}$ were prepared from $\mathrm{Na}-\mathrm{MOR}$ (Südchemie, $\mathrm{Si} / \mathrm{Al}=5$ ) by aqueous ion exchange with $\mathrm{Cu}(\mathrm{II})$ acetate according to the procedure outlined in Vanelderen et al. ${ }^{7}$ From ICP-AES, this resulted in samples with $0.7 \mathrm{mmol} / \mathrm{g} \mathrm{Cu}$ and a $\mathrm{Cu} / \mathrm{Al}$ ratio of 0.4. Samples were pelletized to obtain grain sizes between 0.25 and $0.50 \mathrm{~mm}$ diameter and activated with $\mathrm{O}_{2}$ according to the procedure outlined in ref 7 . Samples were then reacted at $300 \mathrm{~K}$ with either liquid THF under an inert $\mathrm{N}_{2}$ atmosphere, or $10 \% \mathrm{CH}_{4}$ in He carrier gas, and then flame-sealed inside NMR tubes for analysis by resonance Raman spectroscopy ( $\mathrm{rR}$ ).

2.2. Resonance Raman Spectroscopy. rR spectra were recorded at room temperature using a Spex 1877 CP triple monochromator with 1200,1800 , and 2400 grooves/mm holographic spectrograph gratings and an Andor Newton CCD cooled to $-80^{\circ} \mathrm{C}$. The spectral resolution was $2 \mathrm{~cm}^{-1}$. $457.9 \mathrm{~nm}$ excitation was provided by an Innova Sabre 25/7 $\mathrm{Ar}+\mathrm{CW}$ ion laser.
2.3. DFT Calculations. Cluster models were generated from coordinates of the MOR lattice deposited in the IZA-SC Database of Zeolite Structures. ${ }^{8}$ The T4 models incorporated four T4 T-sites, and one additional shell of T-sites capped with hydrides at $1.42 \AA$. In these models, the $\mathrm{T} 4$ sites $(\mathrm{Si} / \mathrm{Al}+$ directly bonded $\mathrm{O}$ atoms) were allowed to relax during geometry optimizations. The T3/T3' models were constructed in a similar fashion. The coordinates of the associated models are reported in the SI. Spin-unrestricted DFT calculations were performed with Gaussian 09, 9 using the B3LYP functional with the GD3 empirical dispersion correction of Grimme included. ${ }^{10}$ The 6-311G* basis set was used for $\mathrm{Cu}$, all ligands coordinated to $\mathrm{Cu}$, and for $\mathrm{CH}_{4}$. The 6-31G* basis set was used for all other atoms. For geometry optimizations of the $\mathrm{T} 3 / \mathrm{T} 3{ }^{\prime}$ and $\mathrm{T} 4$ models, the $\mathrm{T} 3$ and $\mathrm{T} 4$ $\mathrm{T}$-sites (respectively) were allowed to relax while all other $\mathrm{T}$ sites were frozen. Transition state structures were validated through intrinsic reaction coordinate calculations. For the $\mathrm{CH}_{4}$ reaction coordinates, transition state energies were taken from single point calculations performed on optimized structures using the $6-311+G^{*}$ basis set, including zero-point/thermal corrections to activation enthalpies.

\section{RESULTS AND ANALYSIS}

3.1. Locations of $\left[\mathrm{Cu}_{2} \mathrm{O}\right]^{2+}$ Cores in MOR. To determine the locations of MOR1 and MOR2 in the MOR lattice, samples of $\mathrm{Cu}-\mathrm{MOR}$ were reacted with steric probe substrates of various sizes. Methane-a small probe-can access all regions of the MOR lattice, including the side pocket and constricted 8MR channel (see Figure 1). We chose two larger probes with weaker $\mathrm{C}-\mathrm{H}$ bonds - tetrahydrofuran (THF, 92 $\mathrm{kcal} / \mathrm{mol}$ ) and 2,3-dimethylbutane (DMB, $85 \mathrm{kcal} / \mathrm{mol}$ )whose van der Waals dimensions exceed those of the 8MRW separating the $12 \mathrm{MR}$ channel from the side pocket. (The 8MRW opening is $4.5 \AA \times 3.3 \AA$, compared to $5.4 \AA \times 5.4 \AA \times$ $3.0 \AA$ for $\mathrm{THF}$ and $5.5 \AA \times 3.5 \AA \times 6.0 \AA$ for $\mathrm{DMB}$.) We anticipated these bulkier substrates would not be able to access the side pocket, and would instead remain in the open $12 \mathrm{MR}$ channel. The reactions of the $\left[\mathrm{Cu}_{2} \mathrm{O}\right]^{2+}$ cores with these substrates were monitored with $\mathrm{rR}$ spectroscopy, as this selectively probes the $\left[\mathrm{Cu}_{2} \mathrm{O}\right]^{2+}$ cores' characteristic vibrations. ${ }^{6,7}$ Data from the THF reaction are presented here. Data from the DMB reaction are qualitatively consistent with the THF reaction (see Figure S1), but with some additional baseline contributions. For the THF reaction, we focused on the second quanta of the antisymmetric $\mathrm{Cu}-\mathrm{O}-\mathrm{Cu}$ stretching 
modes $\left(2 \nu_{\text {asym }}\right)$, as these features are intense and do not overlap with nonresonant contributions from substrate (see Vanelderen et al. for details, and figure S2 for the corresponding low-frequency region of the $\mathrm{rR}$ data). ${ }^{7}$ As indicated by the arrows in Figure $2 \mathrm{~A}$, the $2 \nu_{\text {asym }}$ features of

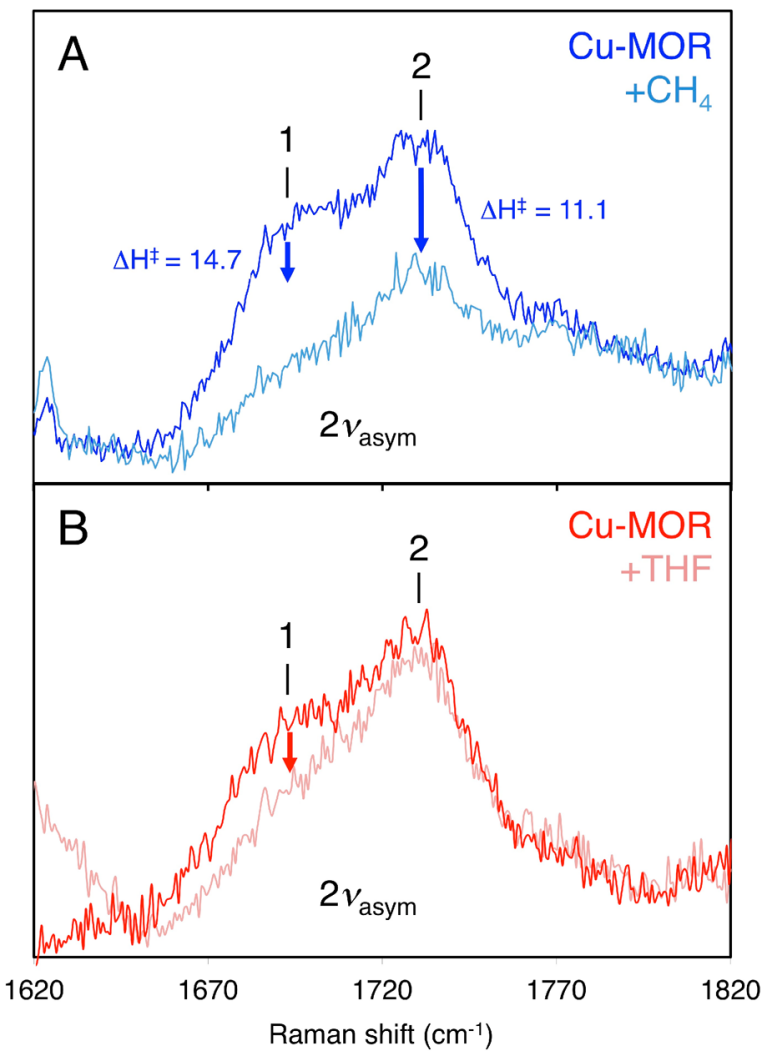

Figure 2. (A) $\mathrm{rR}$ spectra $\left(\lambda_{\mathrm{ex}}=458 \mathrm{~nm}\right)$ of activated Cu-MOR taken before and after reaction with a static atmosphere of $10 \% \mathrm{CH}_{4}$ in $\mathrm{He}$ at $300 \mathrm{~K}$ for $24 \mathrm{~h}$. Some active cores remain after the reaction, contributing on top of an uneven baseline. (B) $r R$ spectra taken before and after reaction with liquid THF at $300 \mathrm{~K}$ for $48 \mathrm{~h}$. Overtones of the antisymmetric $\left(2 \nu_{\text {asym }}\right)$ modes of the bridging oxo ligands of MOR1 (1) and MOR2 (2) are indicated.
MOR1 and MOR2 both decay following reaction with $\mathrm{CH}_{4}$ at room temperature $(300 \mathrm{~K})$ for $24 \mathrm{~h}$. Past studies have quantified the $\mathrm{CH}_{4}$ activation parameters for MOR1 $\left(\Delta H^{\ddagger}=\right.$ $\left.14.7 \mathrm{kcal} / \mathrm{mol}, \Delta S^{\ddagger}=36 \mathrm{cal} / \mathrm{mol} \cdot \mathrm{K}\right)$ and MOR2 $\left(\Delta H^{\ddagger}=11.1\right.$ $\left.\mathrm{kcal} / \mathrm{mol}, \Delta S^{\ddagger}=44 \mathrm{cal} / \mathrm{mol} \cdot \mathrm{K}\right) .^{7}$ After reacting Cu-MOR with liquid THF at $300 \mathrm{~K}$ for $48 \mathrm{~h}$ (Figure $2 \mathrm{~B}$ ), the $2 \nu_{\text {asym }}$ feature of MOR1 decays; however, the MOR2 feature is stable. The decay of MOR2 is therefore more rapid with $\mathrm{CH}_{4}$ relative to THF, and the experimental $\Delta G^{\ddagger}=25 \mathrm{kcal} / \mathrm{mol}$ from Vanelderen et al. $^{7}$ for methane activation by MOR2 at 300 $\mathrm{K}$ gives a conservative lower bound for its much slower reaction with liquid THF at $300 \mathrm{~K}^{7}$

The fact that MOR2 reacts more rapidly with $\mathrm{CH}_{4}$ than THF is interesting, as $\mathrm{CH}_{4}$ has a much stronger $\mathrm{C}-\mathrm{H}$ bond $(104 \mathrm{kcal} / \mathrm{mol}$ versus $92 \mathrm{kcal} / \mathrm{mol}$ for the $\mathrm{C}-\mathrm{H} \alpha$ bonds of THF). This implies the rate-limiting barrier in the reaction between MOR2 and THF is dominated by steric constraints on the approach of the substrate to the active site. MOR2 is therefore located in a sterically constricted region of the zeolite lattice that is not accessible to THF-either the side-pockets or $8 \mathrm{MR}$ channels, but not the 12MR channels (Figure 1). On the other hand, MOR1 decays in the presence of THF at room temperature, and must therefore be located in a less constricted region of the zeolite lattice. This disfavors the side-pocket and $8 \mathrm{MR}$ channels as potential binding locations for MOR1, and supports the more open 12MR channels.

3.2. Computational Definition of MOR1 and MOR2. 3.2.1. $\left[\mathrm{Cu}_{2} \mathrm{O}\right]^{2+}$ Cores in $\mathrm{MOR}$. The location of $\left[\mathrm{Cu}_{2} \mathrm{O}\right]^{2+}$ binding in Cu-zeolites is governed by the distribution of $\mathrm{Al} \mathrm{T}$ site pairs in the parent zeolite lattice that are sufficiently close to support a short $\mathrm{Cu}-\mathrm{Cu}$ separation. ${ }^{6,11,12}$ For the MOR lattices used in this study $(\mathrm{Si} / \mathrm{Al}=5)$, a large body of data from ${ }^{29} \mathrm{Si}$ and ${ }^{27} \mathrm{Al} \mathrm{NMR},{ }^{11,13-15}$ cation siting studies, ${ }^{16-18}$ and X-ray diffraction ${ }^{19}$ indicates that $\mathrm{Al}$ is concentrated at the $\mathrm{T} 3$ and $\mathrm{T} 4$ positions (Figure 1 and Figure 3, left). It is estimated that $\sim 40 \%$ of the T3 sites and $\sim 30 \%$ of the $\mathrm{T} 4$ sites contain $\mathrm{Al}{ }^{19}$ Combined with Loewenstein's rule, ${ }^{20}$ which precludes the existence of $\mathrm{Al}-\mathrm{O}-\mathrm{Al}$ pairs, this requires that a high density of $\mathrm{Al}_{\mathrm{T} 3}-\mathrm{O}-(\mathrm{Si}-\mathrm{O})_{2 / 3}-\mathrm{Al}_{\mathrm{T} 3}$ and $\mathrm{Al}_{\mathrm{T} 4}-\mathrm{O}-(\mathrm{Si}-\mathrm{O})_{2 / 3}-\mathrm{Al}_{\mathrm{T} 4}$ sequences exist in MOR with $\mathrm{Si} / \mathrm{Al}=5 .^{11}(\mathrm{~T} 1 / \mathrm{T} 2 \mathrm{Al} \mathrm{T}$-site pairs stabilize $\left[\mathrm{Cu}_{2} \mathrm{O}\right]^{2+}$ cores with $\mathrm{Cu}-\mathrm{O}-\mathrm{Cu}$ bridge angles that

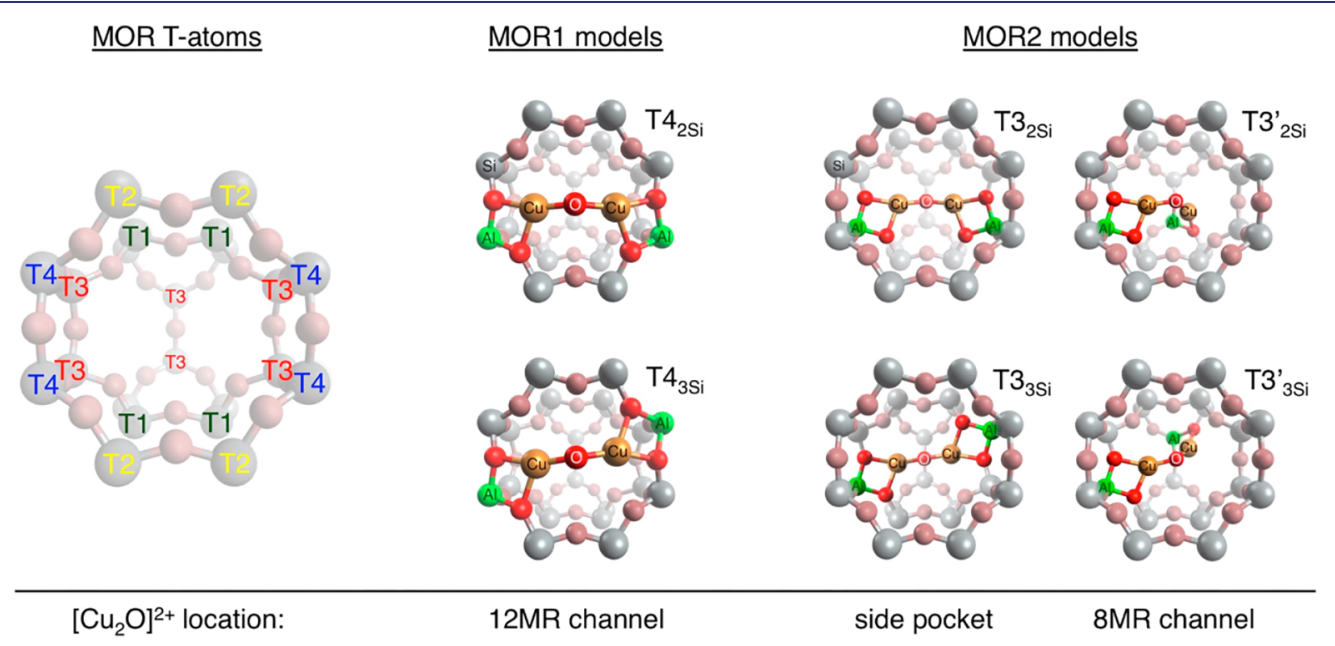

Figure 3. $\left[\mathrm{Cu}_{2} \mathrm{O}\right]^{2+}$ models of MOR1 (T4 models, middle) and MOR2 (T3/T3' models, right) and their locations in the MOR lattice. As a reference, $\mathrm{T}$ atom labels for the relevant portion of the MOR lattice are given in the left of the figure, which shows the $\mathrm{T}$ atoms involved in the side pocket (see Figure 1C). 
are not consistent with the $\sim 140^{\circ}$ experimental values from $\mathrm{rR}$ spectroscopy. ${ }^{21,22}$ Further, the probability of $\mathrm{Al}$ occupation from direct X-ray diffraction is considerably lower for the T1 (9\%) and T2 (6\%) sites. ${ }^{19}$ These low occupations are also consistent with cation siting studies. ${ }^{16-18}$ ) As illustrated in Figure 1B,C (and the left of Figure 3), the T4 atoms are located in the $8 \mathrm{MRW}$ that lies in the wall of the $12 \mathrm{MR}$ channel, and are readily accessed by both $\mathrm{CH}_{4}$ and THF. Sites with $\mathrm{Al}$ at the $\mathrm{T} 4$ positions are therefore models of MOR1. One $\mathrm{Al}_{\mathrm{T} 4}-\mathrm{O}-\mathrm{Si}-\mathrm{O}-\mathrm{Si}-\mathrm{O}-\mathrm{Al}_{\mathrm{T} 4}$ sequence and one $\mathrm{Al}_{\mathrm{T} 4}-\mathrm{O}-$ $\mathrm{Si}-\mathrm{O}-\mathrm{Si}-\mathrm{O}-\mathrm{Si}-\mathrm{O}-\mathrm{Al}_{\mathrm{T} 4}$ sequence can be envisioned in this $8 \mathrm{MRW}$, and the associated $\left[\mathrm{Cu}_{2} \mathrm{O}\right]^{2+}$ models of MOR1 are shown in Figure 3 (middle). Their predicted structural and spectroscopic features ( $\mathrm{rR}, \mathrm{Abs})$ from DFT calculations are tabulated and compared to experimental data in Table 2.

Table 2. Comparison of Experimental Data to the Predicted Structural and Spectroscopic Features of the T4 $\left[\mathrm{Cu}_{2} \mathrm{O}\right]^{2+}$ Models of MOR1

\begin{tabular}{llll} 
& MOR 1 & \multicolumn{1}{c}{$\mathrm{T}_{2 \mathrm{Si}}$} & \multicolumn{1}{c}{$\mathrm{T}_{3 \mathrm{Si}}$} \\
$\angle \mathrm{CuOCu}$ & $137^{\circ}$ & $138^{\circ}$ & $138^{\circ}$ \\
$\mathrm{d}\left(\mathrm{Cu}-\mathrm{O}_{\text {lattice }}\right)(\AA)$ & - & $1.97-2.00$ & $1.98-2.02$ \\
$\mathrm{~d}(\mathrm{Cu}-\mathrm{oxo})(\AA)$ & - & 1.76 & 1.76 \\
$\mathrm{Abs}\left(\mathrm{cm}^{-1}\right)$ & 21900 & 23000 & 23200 \\
$v_{\text {sym }}\left(\mathrm{cm}^{-1}\right)$ & 465 & 440 & 440 \\
$v_{\text {asym }}\left(\mathrm{cm}^{-1}\right)$ & 850 & 865 & 810 \\
$\mathrm{THF} \Delta G^{\ddagger}(\mathrm{kcal} / \mathrm{mol})$ & - & 5 & 5 \\
\hline
\end{tabular}

(These models are labeled according to the position of lattice aluminum substitution- $\mathrm{T} 3$ or $\mathrm{T} 4-$ with subscript indicating the number of $\mathrm{Si} \mathrm{T}$-sites separating the $\mathrm{Al} \mathrm{T}$-sites.) From Figures $1 \mathrm{~B} / \mathrm{C}$ and 3 (left), The T3 positions are located at the intersection of the compressed $8 \mathrm{MR}$ channel and the side pocket-regions of the MOR lattice that are accessible to $\mathrm{CH}_{4}$, but not THF. Sites with $\mathrm{Al}$ at the $\mathrm{T} 3$ positions are therefore models of MOR2. A total of four $\mathrm{Al}_{\mathrm{T} 3}-\mathrm{O}-(\mathrm{Si}-\mathrm{O})_{2 / 3}-\mathrm{Al}_{\mathrm{T} 3}$ sequences can be envisioned, resulting in the four $\left[\mathrm{Cu}_{2} \mathrm{O}\right]^{2+}$ models of MOR2 shown in Figure 3 (right). These cores bind in either the side pocket $\left(\mathrm{T} 3_{2 \mathrm{Si}}\right.$ and $\left.\mathrm{T} 3_{3 \mathrm{Si}}\right)$, or across the $8 \mathrm{MR}$ channel $\left(\mathrm{T}^{\prime}{ }_{2 \mathrm{Si}}\right.$ and $\left.\mathrm{T}^{\prime}{ }_{3 \mathrm{Si}}\right)$. Their predicted structural and spectroscopic features are tabulated and compared to experimental data in Table 3. Finally, mixed T3/T4 sequences (e.g., $\left.\mathrm{Al}_{\mathrm{T} 3}-\mathrm{O}-(\mathrm{Si}-\mathrm{O})_{3}-\mathrm{Al}_{\mathrm{T} 4}\right)$ give $\mathrm{Al}-\mathrm{Al}$ separations that are either too small to stabilize $\left[\mathrm{Cu}_{2} \mathrm{O}\right]^{2+}$ sites with bridge angles of $\sim 140^{\circ}$, or too large to stabilize a $2 \mathrm{Cu}(\mathrm{I})$ precursor site with a short $\mathrm{Cu}-\mathrm{Cu}$ separation (a requirement for $\left[\mathrm{Cu}_{2} \mathrm{O}\right]^{2+}$ formation). ${ }^{12}$

3.2.2. $\left[\mathrm{Cu}_{2} \mathrm{O}\right]^{2+}$ Spectroscopic Features. The $\left[\mathrm{Cu}_{2} \mathrm{O}\right]^{2+}$ models of MOR1 and MOR2 in Figure 3 all feature threecoordinate $\mathrm{Cu}(\mathrm{II})$ centers with highly similar first coordination spheres $\left(\mathrm{d}\left(\mathrm{Cu}-\mathrm{O}_{\text {lattice }}\right)=1.96-2.02 \AA, \mathrm{d}(\mathrm{Cu}-\right.$ oxo $)=1.75-$ $1.76 \AA$ ) and electronic structures (see Figure S3). Comparing the structural and spectroscopic features of the $\mathrm{T} 4_{2 \mathrm{Si}}$ and $\mathrm{T} 4_{3 \mathrm{Si}}$ models of MOR1 in Table 2, the predicted $\mathrm{Cu}-\mathrm{O}-\mathrm{Cu}$ angles of $138^{\circ}$ agree well with the experimental value from $\mathrm{rR}$ data $\left(137^{\circ}\right) .^{7}$ The symmetric and antisymmetric $\mathrm{Cu}-\mathrm{O}-\mathrm{Cu}$ stretching frequencies, oxo $\rightarrow \mathrm{Cu}$ (II) LMCT energies, and $\mathrm{CH}_{4}$ reactivity of these cores (vide infra) also agree well with experiment. Finally, as determined in 3.3, both MOR1 models perform HAA from THF with a low barrier of $5 \mathrm{kcal} /$ mol. The $\mathrm{T} 4_{3 \mathrm{Si}}$ model was chosen as representative of MOR1; however, sites resembling $\mathrm{T}_{2 \mathrm{Si}}$ may also be present and effectively indistinguishable from $\mathrm{T} 4_{3 \mathrm{Si}}$-like sites.

For the models of MOR2 compared in Table 3, the predicted $\mathrm{Cu}-\mathrm{O}-\mathrm{Cu}$ angles of $\mathrm{T} 3_{2 \mathrm{Si}}\left(144^{\circ}\right), \mathrm{T} 3_{3 \mathrm{Si}}\left(143^{\circ}\right)$, and $\mathrm{T}^{\prime}{ }_{3 \mathrm{Si}}\left(131^{\circ}\right)$ are in reasonable agreement with the experimental value from $\mathrm{rR}$ data $\left(138-141^{\circ}\right){ }^{7}$ The bridge angle of the $\mathrm{T}^{\prime}{ }_{2 \mathrm{Si}}$ model $\left(123^{\circ}\right)$ is more acute. Consistent with their $\mathrm{Cu}-\mathrm{O}-\mathrm{Cu}$ angles, the predicted symmetric and antisymmetric $\mathrm{Cu}-\mathrm{O}-\mathrm{Cu}$ stretching frequencies for $\mathrm{T} 3_{2 \mathrm{~S}}$, $\mathrm{T} 3_{3 \mathrm{Si}}$, and $\mathrm{T} 3^{\prime}{ }_{3 \mathrm{Si}}$ are in reasonable agreement with experiment; but again there is poor agreement for $\mathrm{T} 3^{\prime}{ }_{2 \mathrm{Si}}\left(\nu_{\text {sym }}\right.$ is high and $\nu_{\text {asym }}$ is low for this core, reflecting its more acute bridge angle). The LMCT energies of all T3/T3' models (23000-25000 $\left.\mathrm{cm}^{-1}\right)$ are all in agreement with experiment $\left(23100 \mathrm{~cm}^{-1}\right)$. As shown in figure S4, the experimental $23100 \mathrm{~cm}^{-1}$ band of MOR2 is broad with a high-energy shoulder. ${ }^{7}$ This high-energy shoulder is reproduced only by the $\mathrm{T} 3^{\prime}$ models in the $8 \mathrm{MR}$ channel. TD-DFT indicates this is due to a low-symmetry splitting of the LMCT band for the T3' cores, reflecting their inequivalent $\mathrm{Cu}(\mathrm{II})$ ligand fields. As presented in 3.3, All four MOR2 models predict a THF activation barrier of $\Delta G^{\ddagger}=38$ $\mathrm{kcal} / \mathrm{mol}$ at $300 \mathrm{~K}$, consistent with a reaction half-life of years.

From the above analysis, the $\mathrm{T}^{\prime}{ }_{3 \mathrm{Si}}$ model is in good agreement with all available spectroscopic and THF reactivity data from MOR2. $\mathrm{T}^{\prime}{ }_{2 \mathrm{Si}}$ is ruled out based on poor agreement with $\mathrm{rR}$ data and its acute $\mathrm{Cu}-\mathrm{O}-\mathrm{Cu}$ angle. And while most of the predicted spectroscopic features of $\mathrm{T} 3_{2 \mathrm{Si}}$ and $\mathrm{T} 3_{3 \mathrm{Si}}$ are in reasonable agreement with experiment, these sites can be excluded based on their reactivity with $\mathrm{CH}_{4}$ (vide infra). We therefore identify the $\mathrm{T}^{\prime}{ }_{3 \mathrm{Si}}$ model as representative of MOR2.

3.3. Computational Evaluation of $\mathbf{H}$ Atom Abstraction Reaction Coordinates. $\mathrm{CH}_{4} \mathrm{H}$ atom abstraction transition states were located on the triplet surface for MOR1 $\left(\mathrm{T}_{3 \mathrm{Si}}\right.$ model in Figure 3 ) and MOR2 ( ${ }^{\prime}{ }^{\prime}{ }_{3 \mathrm{Si}}$ model in Figure 3), following the approach of Woertink et al. ${ }^{6}$ These transition states are compared in Figure 4. The starting point for each reaction coordinate was taken as the van der Waals complex between $\mathrm{CH}_{4}$ and an $8 \mathrm{MRW}$ exposed to the $12 \mathrm{MR}$ channel (Figure 4A). Methane can then desorb into the 12MR

Table 3. Comparison of Experimental Data to the Predicted Structural and Spectroscopic Features of the $\mathrm{T} 3 / \mathrm{T}^{\prime}\left[\mathrm{Cu}_{2} \mathrm{O}\right]^{2+}$ Models of MOR2

\begin{tabular}{|c|c|c|c|c|c|}
\hline & MOR2 & $\mathrm{T} 3_{2 \mathrm{Si}}$ & $\mathrm{T} 3_{3 \mathrm{Si}}$ & $\mathrm{T}^{\prime}{ }_{2 \mathrm{Si}}$ & $\mathrm{T}^{\prime}{ }_{3 \mathrm{Si}}$ \\
\hline$\angle \mathrm{CuOCu}$ & $141-138^{\circ}$ & $144^{\circ}$ & $143^{\circ}$ & $123^{\circ}$ & $131^{\circ}$ \\
\hline $\mathrm{d}\left(\mathrm{Cu}-\mathrm{O}_{\text {lattice }}\right)(\AA)$ & - & $1.96-2.01$ & $1.98-2.02$ & $1.97-2.02$ & $1.96-2.01$ \\
\hline $\mathrm{d}(\mathrm{Cu}-\mathrm{oxo})(\AA)$ & - & 1.75 & 1.75 & $1.75,1.76$ & $1.75,1.75$ \\
\hline $\operatorname{Abs}\left(\mathrm{cm}^{-1}\right)$ & $23100+$ shoulder & 23000 & 23400 & $25000+$ shoulder & $23800+$ shoulder \\
\hline$v_{\text {sym }}\left(\mathrm{cm}^{-1}\right)$ & $450-470$ & 420 & 450 & 500 & 470 \\
\hline$v_{\text {asym }}\left(\mathrm{cm}^{-1}\right)$ & 870 & 880 & 855 & 795 & 830 \\
\hline THF $\Delta G^{\ddagger}(\mathrm{kcal} / \mathrm{mol})$ & $>25$ & 38 & 38 & 38 & 38 \\
\hline
\end{tabular}




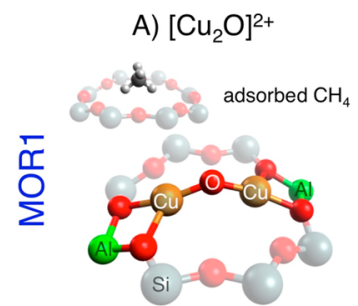

B) reactant complex

C) HAA TS

D) $\left[\mathrm{Cu}_{2} \mathrm{OH}\right]^{2+}+\mathrm{CH}_{3}$
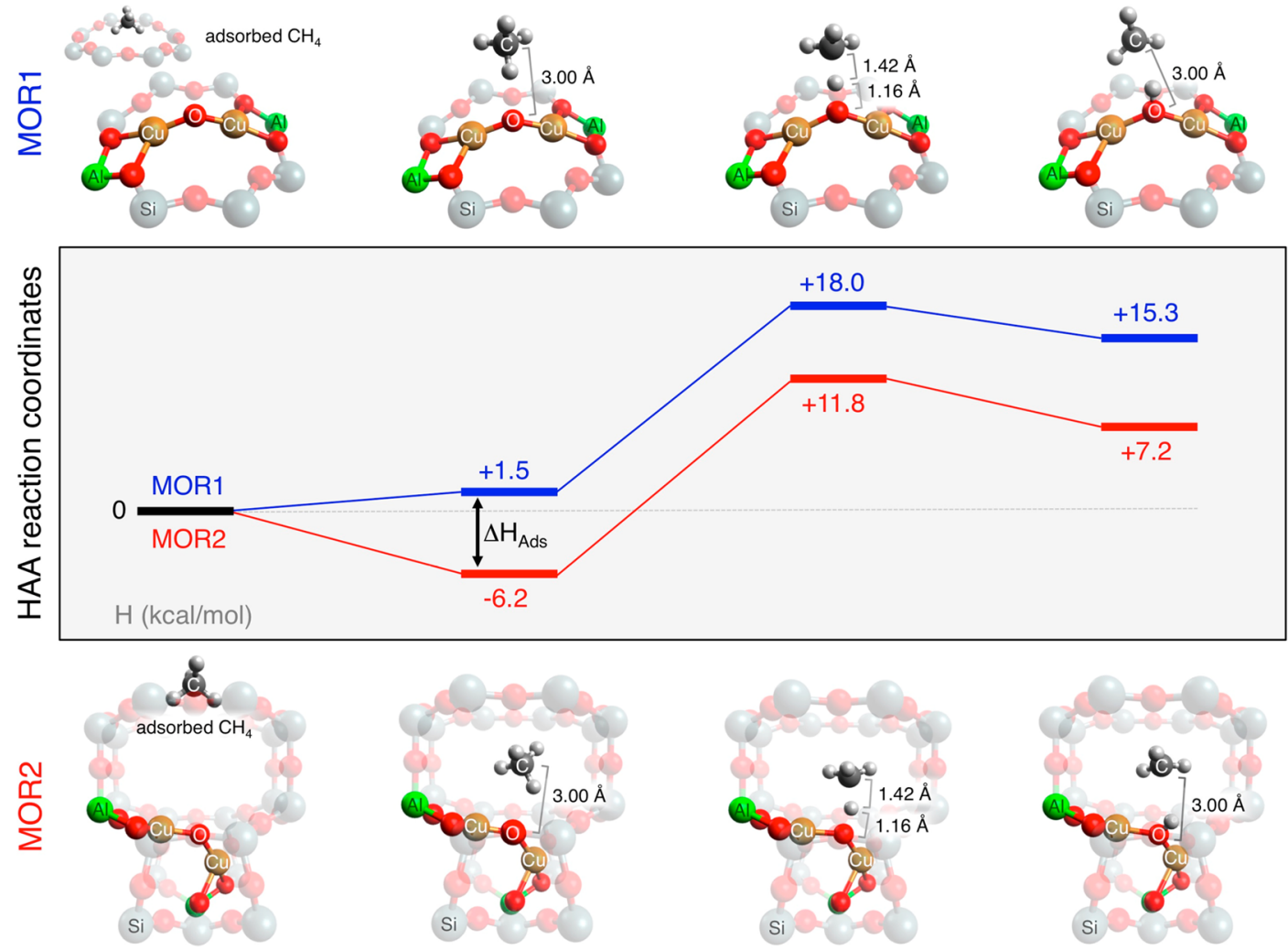

Figure 4. Comparison of the $\mathrm{CH}_{4} \mathrm{H}$ atom abstraction reaction coordinates of MOR1 (top, blue) and MOR2 (bottom, red), moving from the $\left[\mathrm{Cu}_{2} \mathrm{O}\right]^{2+}$ core (A), to the reactant complex (B), transition state (C), and product complex (D). $\Delta H_{\mathrm{Ads}}$ quantifies the predicted enthalpy of $\mathrm{CH}_{4}$ adsorption into the side pocket.

channel to form an approach complex with MOR1 defined by a $\mathrm{d}(\mathrm{C}-\mathrm{O})=3.0 \AA$ (Figure $4 \mathrm{~B}$, top). This step is uphill by $\Delta H$ $=1.5 \mathrm{kcal} / \mathrm{mol}$ due to loss of van der Waals interactions between the $\mathrm{CH}_{4}$ and the zeolite lattice. The $\mathrm{H}$ atom abstraction transition state (Figure 4C, top) is associated with an apparent activation barrier of $\Delta H^{*}=18 \mathrm{kcal} / \mathrm{mol}$, in reasonable agreement with the experimental (apparent) barrier of $14.7 \mathrm{kcal} / \mathrm{mol}^{7}$ and very similar to the $\Delta H^{\ddagger}=18.5 \mathrm{kcal} / \mathrm{mol}$ predicted for the $\left[\mathrm{Cu}_{2} \mathrm{O}\right]^{2+}$ cores in Cu-ZSM-5. ${ }^{6}$ At the MOR1 transition state, the core polarizes toward an activated $\mathrm{Cu}$-oxyllike electronic structure. Past studies also identified this as an important electronic structure contribution to the high reactivity of $\mathrm{Cu}-\mathrm{ZSM}-5{ }^{6}$ This $\mathrm{FMO}$ polarization is facilitated by high $\mathrm{Cu}$ /oxo covalency, ${ }^{2,6}$ evident from the intense low energy oxo $\rightarrow \mathrm{Cu}(\mathrm{II})$ LMCTs of these $\left[\mathrm{Cu}_{2} \mathrm{O}\right]^{2+}$ cores. ${ }^{6,7}$ Moving past the transition state yields the $\left[\mathrm{Cu}_{2} \mathrm{OH}\right]^{2+}$ first product of HAA (Figure 4D, top). Comparing the reactant and product complexes, the HAA reaction is found to be endothermic by only $13.8 \mathrm{kcal} / \mathrm{mol}$ due to the formation of a strong $90 \mathrm{kcal} / \mathrm{mol} \mathrm{O}-\mathrm{H}$ bond in the product. This is an important thermodynamic contribution to the low barrier for HAA. $^{6}$

For MOR2, methane can leave the 12MR channel (Figure $4 \mathrm{~A}$, bottom) and enter the side pocket to form the approach complex shown at the bottom of Figure 4B. In contrast to MOR1, for MOR2 this step is downhill by $\Delta H=-6.2 \mathrm{kcal} /$ mol due to close van der Waals contact between $\mathrm{CH}_{4}$ and the walls of the side pocket. To ensure an accurate DFT description of this noncovalent interaction between $\mathrm{CH}_{4}$ and the zeolite lattice, the DFT functional used in the present
study-B3LYP with the GD3 empirical dispersion correction of Grimme ${ }^{10}$ - was benchmarked against experimental gas adsorption data. Two $\mathrm{CH}_{4}$ adsorption sites exist in MOR. ${ }^{23,24}$ At low coverage $\left(<1 \mathrm{CH}_{4}\right.$ per unit cell), the more stable site is preferentially occupied, with an isosteric heat of adsorption of $-7.2 \mathrm{kcal} / \mathrm{mol}$. There is consensus from experiment and theory that this represents adsorption of methane into the side pocket. $^{23-26}$ This correlates to the predicted $\Delta H_{\mathrm{Ads}}=-7.7$ $\mathrm{kcal} / \mathrm{mol}$ from the enthalpy difference between the approach complexes for MOR1 and MOR2 in Figure 4B-in close agreement with the experimental value. At higher coverage $(>1$ $\mathrm{CH}_{4}$ per unit cell), methane also occupies the large $12 \mathrm{MR}$ channel. Gas adsorption data coupled to MD simulations indicate the adsorption enthalpy of $\mathrm{CH}_{4}$ in the $12 \mathrm{MR}$ channel is $4-6 \mathrm{kcal} / \mathrm{mol}$. Comparing experiment to theory, B3LYP +GD3 predicts a $4 \mathrm{kcal} / \mathrm{mol}$ adsorption enthalpy for $\mathrm{CH}_{4}$ in the 12MR (modeled as the van der Waals complexes in Figure 4A). These values agree well with past experimental and theoretical work in refs 24-28. Upon removing empirical dispersion, $\mathrm{CH}_{4}$ adsorption is predicted to be uphill in enthalpy by 1.1 and $2.0 \mathrm{kcal} / \mathrm{mol}$ for binding at the side pocket and $12 \mathrm{MR}$, respectively. Empirical dispersion is therefore required to accurately model noncovalent $\mathrm{CH}_{4}$-zeolite interactions, in agreement with DFT studies in the literature. ${ }^{24,27,28}$

Proceeding from the MOR2 reactant complex to the HAA transition state at the bottom of Figure 4C, the true (not apparent) barrier is calculated to be $18 \mathrm{kcal} / \mathrm{mol}$ - similar to the experimental barriers for MOR1 and ZSM-5. As shown in $\mathrm{S} 3$, the electronic structure of the MOR2 transition state is 
highly similar to MOR1. Comparing the enthalpy change moving from the reactant complex to the $\left[\mathrm{Cu}_{2} \mathrm{OH}\right]^{2+}$ first product complex (Figure 4D, bottom), the MOR2 HAA reaction is endothermic by $13.4 \mathrm{kcal} / \mathrm{mol}$ (versus $13.8 \mathrm{kcal} /$ mol for MOR1). As originally proposed in Vanelderen et al., the subtle differences between the geometric and electronic structures of MOR1/MOR2 seen experimentally and reproduced here by DFT calculations do not explain the different reactivities of these cores. Instead, the predicted $6.2 \mathrm{kcal} / \mathrm{mol}$ reduction of the apparent barrier for MOR2 relative to MOR1 in Figure 4C reflects the van der Waals stabilization of substrate adsorbed in the side pocket (Figure 4B, bottom). A similar $5.6 \mathrm{kcal} / \mathrm{mol}$ reduction of the MOR2 barrier is predicted using the BP86+GD3 functional, indicating this result is robust with respect to the choice of DFT method. (As with B3LYP, no reduction is predicted in the absence of GD3 dispersion.) This defines the role of the zeolite lattice in tuning down the $\mathrm{CH}_{4}$ HAA barrier for MOR2.

The fact that a $\left[\mathrm{Cu}_{2} \mathrm{O}\right]^{2+}$ site in a constricted location can react with a low barrier is particularly interesting, as this places strict constraints on the trajectory of substrate approach. This can be seen by comparing the $\mathrm{CH}_{4} \mathrm{HAA}$ transition state structure of MOR2 ( $\left.\mathrm{T}^{\prime}{ }_{3 \mathrm{Si}}\right)$ in Figure $5 \mathrm{~A}$ to that of the $\mathrm{T}_{3} \mathrm{Si}_{\mathrm{i}}$

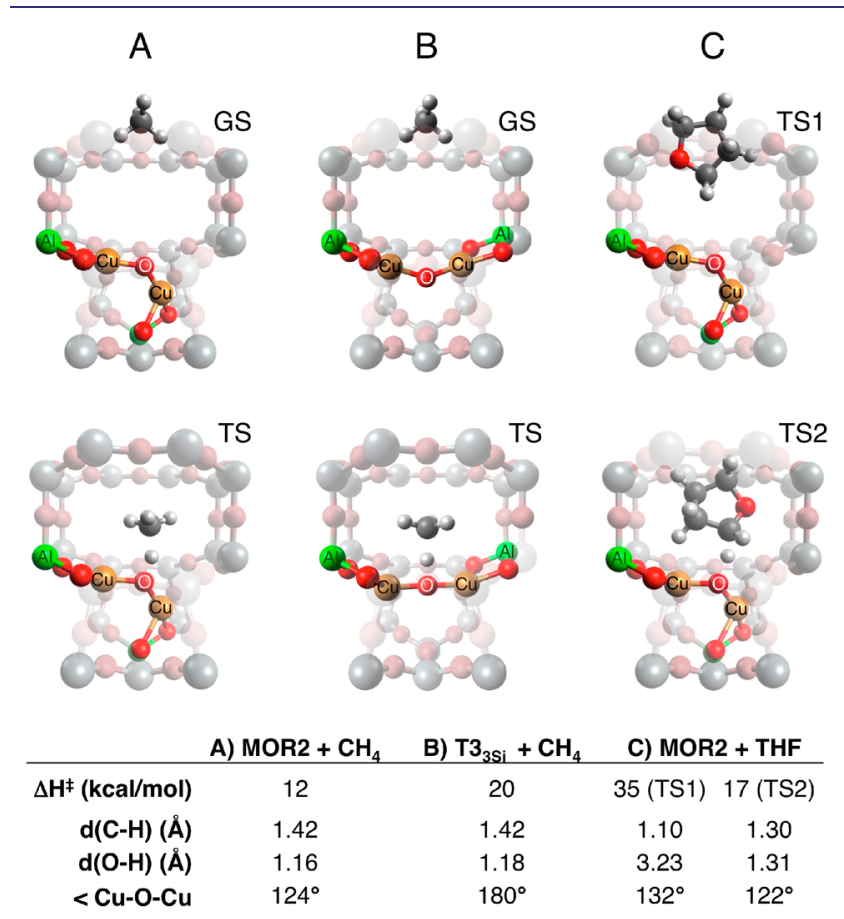

Figure 5. Comparison of the $\mathrm{CH}_{4} \mathrm{HAA}$ TS structures and activation enthalpies for (A) MOR2 ( $\mathrm{T}^{\prime}{ }_{3 \mathrm{Si}}$ model) and (B) the $\mathrm{T} 3_{3 \mathrm{Si}}$ model. For comparison, the corresponding ground state geometries are shown above the transition state structures. (C) The rate limiting TS for the THF reaction with MOR2, involving transit of THF into the side pocket (TS1), and subsequent TS for HAA (TS2).

model in Figure 5B. The $\mathrm{T} 3_{3 \mathrm{Si}}$ site resembles the DFT model studied by Zhao et al., ${ }^{21}$ which predicted a $36 \mathrm{kcal} / \mathrm{mol} \mathrm{HAA}$ barrier for substrate approaching from the sterically demanding $8 \mathrm{MR}$ channel. ${ }^{21}$ We predict a similar barrier for this approach trajectory $\left(\Delta H^{\ddagger}=34 \mathrm{kcal} / \mathrm{mol}\right)$. However, the barrier is substantially reduced for substrate approach through the side pocket $\left(\Delta H^{\ddagger}=20 \mathrm{kcal} / \mathrm{mol}\right)$. Nonetheless, this is still much higher than the experimental value of $11.1 \mathrm{kcal} / \mathrm{mol}$. The large
$\mathrm{T} 3_{3 \mathrm{Si}}$ activation barrier reflects a large distortion of $\angle \mathrm{Cu}-\mathrm{O}-$ $\mathrm{Cu}$ at the TS $\left(\angle \mathrm{Cu}-\mathrm{O}-\mathrm{Cu}\right.$ increases from $143^{\circ}$ in the ground state to $180^{\circ}$ at the TS). This distortion occurs because the reactive oxo is initially oriented into the $8 \mathrm{MR}$ channel, and the core must invert its orientation to interact with substrate in the side pocket. To clarify why a buried site with diminished reactivity like $\mathrm{T} 3_{3 \mathrm{Si}}$ is not seen experimentally, we evaluated the relative stabilities of the associated $2 \mathrm{Cu}(\mathrm{I})$ models and found that the $\mathrm{T} 3_{3 \mathrm{Si}}$ precursor is $11 \mathrm{kcal} / \mathrm{mol}$ less stable than the $\mathrm{T}^{\prime}{ }_{3 \mathrm{Si}}$ precursor.

In contrast to $\mathrm{T}_{3 \mathrm{Si}}$, the reactive oxo of MOR2 $\left(\mathrm{T}^{\prime}{ }_{3 \mathrm{Si}}\right)$ in Figure $5 \mathrm{~A}$ is oriented into the side pocket, resulting in minimal distortions of the $\left[\mathrm{Cu}_{2} \mathrm{O}\right]^{2+}$ core at the transition state $(\angle \mathrm{Cu}-$ $\mathrm{O}-\mathrm{Cu}$ decreases by $\left.7^{\circ}\right)$. The MOR lattice therefore facilitates reactivity with $\mathrm{CH}_{4}$ by binding MOR2 in an orientation that minimizes steric contributions to the HAA barrier. For THF, on the other hand, the rate-limiting barrier of $\Delta H^{\ddagger}=35 \mathrm{kcal} /$ mol in its reaction with MOR2 is associated with transit of THF into the side-pocket (TS1 in Figure 5C), resulting in significant steric repulsion between the substrate and lattice, but minimal distortions of the $\left[\mathrm{Cu}_{2} \mathrm{O}\right]^{2+}$ core and substrate $\mathrm{C}-$ $\mathrm{H}$ bond. On the basis of this model, only linear hydrocarbons would be able to pass unhindered through the $8 \mathrm{MRW}$; a steric barrier would be present for branched (e.g., DMB) and cyclic hydrocarbons. The subsequent HAA step proceeds with a lower $17 \mathrm{kcal} / \mathrm{mol}$ barrier (TS2 in Figure 5C) once the substrate enters the side-pocket. However, this barrier still exceeds the apparent $\Delta H^{+}=12 \mathrm{kcal} / \mathrm{mol}$ for $\mathrm{CH}_{4}$ activation, as well as the $\Delta H^{+}=5 \mathrm{kcal} / \mathrm{mol}$ predicted for the reaction of THF with MOR1, where no steric constraints on the substrate are present. This highlights the interplay between dispersion and sterics in the active site pocket of MOR2.

\section{DISCUSSION}

Two $\left[\mathrm{Cu}_{2} \mathrm{O}\right]^{2+}$ cores have been identified in $\mathrm{Cu}-\mathrm{MOR}$ with similar geometric and electronic structures, yet distinct reactivity with $\mathrm{CH}_{4}$ and THF. While both cores-MOR1 and MOR2-react with $\mathrm{CH}_{4}$ at $300 \mathrm{~K}, \mathrm{MOR} 2$ has a $3.6 \mathrm{kcal} /$ $\mathrm{mol}$ lower activation enthalpy coupled to an $8 \mathrm{cal} / \mathrm{mol} \cdot \mathrm{K}$ more negative activation entropy. ${ }^{7}$ It was previously suggested that this reactivity difference reflects substrate confinement effects. ${ }^{7}$ To evaluate this idea, $\mathrm{Cu}-\mathrm{MOR}$ was reacted with a bulky probe substrate with a relatively weak $\mathrm{C}-\mathrm{H}$ bond (THF). It was found that THF reacts selectively with MOR1, but not MOR2, confirming MOR2 is located in a constricted location of the zeolite lattice. To clarify how a $\left[\mathrm{Cu}_{2} \mathrm{O}\right]^{2+}$ core in a constricted environment can react with a lower barrier than an unconstricted site, six $\left[\mathrm{Cu}_{2} \mathrm{O}\right]^{2+}$ DFT models were constructed and evaluated against experimental spectroscopic and reactivity data. This defined two structural models: one representative of MOR1 located at the intersection of the side pocket and the $12 \mathrm{MR}$ channel (unconstricted), and one of MOR2 located at the intersection of the side pocket and $8 \mathrm{MR}$ channel (constricted). Comparing the DFT HAA reaction coordinates for MOR1 and MOR2, we found the lower methane activation enthalpy of MOR2 derives from the enthalpy of substrate adsorption into the side pocket. The confinement of substrate in the side pocket is also likely responsible for the $8 \mathrm{cal} / \mathrm{mol} \cdot \mathrm{K}$ more negative entropy of activation for MOR2. This defines the role of the zeolite lattice in tuning the reactivity of this $\left[\mathrm{Cu}_{2} \mathrm{O}\right]^{2+}$ core.

The present study highlights an important mechanism to tune the reactivity of metal active sites in zeolites. Past efforts 
have focused on the bonding interaction between active sites and the zeolite lattice, and how this leads to geometric/ electronic structures that are activated for function. 2,3,6,21,22 However, for $\mathrm{Cu}-\mathrm{MOR}$, experimental data coupled to DFT shows that noncovalent interactions between the zeolite lattice and the substrate also make a significant contribution, and that the adsorption of substrate into an active site pocket can enhance reactivity. From a structural standpoint, the curvature of the lattice is an important parameter in tuning substrate adsorption. $^{29,30}$ For small substrates, high curvature favors adsorption by enabling close van der Waals contact with the lattice-e.g., $\mathrm{CH}_{4}$ adsorption into the side pocket during its reaction with MOR2 (Figure 4, bottom). On the other hand, a mismatch between the lattice curvature and the size of the substrate can either (1) have no effect on reactivity, as in the reaction of methane with MOR1 in the large 12MR channel; or (2) have a deleterious effect, leading to a steric high barrier between THF and MOR2 in the side pocket. This enhanced reactivity due to substrate adsorption is a manifestation of the "nest effect"-a concept from shape-selective catalysis that emerged from studies of hydrocarbon cracking in acid zeolites. $^{29-32}$ In these studies, it was found that catalytic rates are maximized when the zeolite pores match the dimensions of the substrate. This drives adsorption into the pores, enhancing the interaction of substrate with the active sites therein.

The experimental observation of a "nest effect" in metallozeolite chemistry is significant, as a single type of metal active site can often be stabilized in many different lattice topologies. (In addition to $\mathrm{Cu}-\mathrm{MOR}$ and $\mathrm{Cu}-\mathrm{ZSM}-5,\left[\mathrm{Cu}_{2} \mathrm{O}\right]^{2+}$ cores are also reported in $\mathrm{Cu}-\mathrm{CHA}$ and $\mathrm{Cu}-\mathrm{AEI} .^{33-35}$ And in analogy to the $\mathrm{Cu}$-zeolites, the $[\mathrm{Fe}=\mathrm{O}]^{2+}$ active site of low temperature methane hydroxylation in Fe-zeolites forms in Fe-ZSM-5, FeBEA, Fe-FER, and Fe-ZSM-11.) ${ }^{2-4}$ As a result, the active site pocket of a metal center in a zeolite can be thought of as tunable parameter, with dimensions that can be matched to a substrate or reaction of interest. It will be of interest to explore how this selective adsorption effect can influence subsequent steps in methanol synthesis. For example, hindered access of the bulkier methanol product to a constricted active site could disfavor overoxidation-reminiscent of the substrate selectivity enforced by the active site pocket of a metalloenzyme. This concept of adsorption-enhanced reactivity could also be applied to different reactions (e.g., conversion of benzene to phenol), and extended to metal active sites in other microporous materials such as metal-organic frameworks.

\section{CONCLUSION}

Two $\left[\mathrm{Cu}_{2} \mathrm{O}\right]^{2+}$ cores have been identified in the zeolite $\mathrm{Cu}$ MOR having similar geometric and electronic structures, yet different reactivity with $\mathrm{CH}_{4}$. In the present study, we couple experimental spectroscopic reactivity studies to DFT calculations to arrive at structural models of the $\mathrm{Cu}-\mathrm{MOR}$ active sites. The more reactive core is found to be located in a constricted region of the zeolite lattice, leading to close van der Waals contact between the substrate and the zeolite lattice in the vicinity of the active site. The resulting enthalpy of substrate adsorption drives the subsequent $\mathrm{H}$ atom abstraction step-a manifestation of the "nest" effect seen in hydrocarbon cracking on acid zeolites. This defines a mechanism to tune the reactivity of metal active sites in microporous materials.

\section{ASSOCIATED CONTENT}

\section{Supporting Information}

The Supporting Information is available free of charge on the ACS Publications website at DOI: 10.1021/jacs.8b05320.

UV-vis-NIR and resonance Raman spectra of $\mathrm{Cu}$ MOR after reaction with 2,3-dimethylbutane, resonance Raman spectra of $\mathrm{Cu}-\mathrm{MOR}$ after reaction with THF, electronic structures of $\left[\mathrm{Cu}_{2} \mathrm{O}\right]^{2+}$ DFT models (Mulliken charges and spins), TD-DFT calculations, DFT cluster model coordinates (PDF)

\section{AUTHOR INFORMATION}

\section{Corresponding Authors}

*robert.schoonheydt@biw.kuleuven.be

*bert.sels@biw.kuleuven.be

*edward.solomon@stanford.edu

ORCID

Bert F. Sels: 0000-0001-9657-1710

Edward I. Solomon: 0000-0003-0291-3199

Notes

The authors declare no competing financial interest.

\section{ACKNOWLEDGMENTS}

B.E.R.S. acknowledges support from National Science Foundation Graduate Research Fellowship Program Grant DGE-11474 and from the Munger, Pollock, Reynolds, Robinson, Smith, and Yoedicke Stanford Graduate Fellowship. Funding for this work was provided by National Science Foundation Grant CHE-1660611 (to E.I.S.) and Research Foundation - Flanders Grant G0A2216N (to B.F.S.). We would like to thank Max Bols and Dieter Plessers for helpful comments on this manuscript.

\section{REFERENCES}

(1) Ross, M. O.; Rosenzweig, A. C. JBIC, J. Biol. Inorg. Chem. 2017, 22 (2), 307-319.

(2) Snyder, B. E. R.; Bols, M. L.; Schoonheydt, R. A.; Sels, B. F.; Solomon, E. I. Chem. Rev. 2018, 118 (5), 2718-2768.

(3) Snyder, B. E. R.; Vanelderen, P.; Bols, M. L.; Hallaert, S. D.; Böttger, L. H.; Ungur, L.; Pierloot, K.; Schoonheydt, R. A.; Sels, B. F.; Solomon, E. I. Nature 2016, 536 (7616), 317-321.

(4) Snyder, B. E. R.; Böttger, L. H.; Bols, M. L.; Yan, J. J.; Rhoda, H. M.; Jacobs, A. B.; Hu, M. Y.; Zhao, J.; Alp, E. E.; Hedman, B.; Hodgson, K. O.; Schoonheydt, R. A.; Sels, B. F.; Solomon, E. I. Proc. Natl. Acad. Sci. U. S. A. 2018, 115 (18), 4565-4570.

(5) Grundner, S.; Markovits, M. A. C.; Li, G.; Tromp, M.; Pidko, E. A.; Hensen, E. J. M.; Jentys, A.; Sanchez-Sanchez, M.; Lercher, J. A. Nat. Commun. 2015, 6, 7546.

(6) Woertink, J. S.; Smeets, P. J.; Groothaert, M. H.; Vance, M. A.; Sels, B. F.; Schoonheydt, R. A.; Solomon, E. I. Proc. Natl. Acad. Sci. U. S. A. 2009, 106 (45), 18908-18913.

(7) Vanelderen, P.; Snyder, B. E. R.; Tsai, M.-L.; Hadt, R. G.; Vancauwenbergh, J.; Coussens, O.; Schoonheydt, R. A.; Sels, B. F.; Solomon, E. I. J. Am. Chem. Soc. 2015, 137 (19), 6383-6392.

(8) Baerlocher, C.; McCusker, L. B. http://www.iza-structure.org/ databases/ (accessed Feb 4, 2018).

(9) Frisch, M. J.; Trucks, G. W.; Schlegel, H. B.; Scuseria, G. E.; Robb, M. A.; Cheeseman, J. R.; Scalmani, G.; Barone, V.; Mennucci, B.; Petersson, G. A.; Nakatsuji, H.; Caricato, M.; Li, X.; Hratchian, H. P.; Izmaylov, A. F.; Bloino, J.; Zheng, G.; Sonnenberg, J. L.; Hada, M.; Ehara, M.; Toyota, K.; Fukuda, R.; Hasegawa, J.; Ishida, M.; Nakajima, T.; Honda, Y.; Kitao, O.; Nakai, H.; Vreven, T.; Montgomery, J. A., Jr.; Peralta, J. E.; Ogliaro, F.; Bearpark, M.; Heyd, J. J.; Brothers, E.; Kudin, K. N.; Staroverov, V. N.; Kobayashi, 
R.; Normand, J.; Raghavachari, K.; Rendell, A.; Burant, J. C.; Iyengar, S. S.; Tomasi, J.; Cossi, M.; Rega, N.; Millam, J. M.; Klene, M.; Knox, J. E.; Cross, J. B.; Bakken, V.; Adamo, C.; Jaramillo, J.; Gomperts, R.; Stratmann, R. E.; Yazyev, O.; Austin, A. J.; Cammi, R.; Pomelli, C.; Ochterski, J. W.; Martin, R. L.; Morokuma, K.; Zakrzewski, V. G.; Voth, G. A.; Salvador, P.; Dannenberg, J. J.; Dapprich, S.; Daniels, A. D.; Farkas, Ö.; Foresman, J. B.; Ortiz, J. V.; Cioslowski, J.; Fox, D. J. Gaussian 09; Gaussian, Inc.: Wallingford, CT, 2009.

(10) Grimme, S.; Antony, J.; Ehrlich, S.; Krieg, H. J. Chem. Phys. 2010, 132 (15), 154104.

(11) Dědeček, J.; Sobalík, Z.; Wichterlová, B. Catal. Rev.: Sci. Eng. 2012, 54 (2), 135-223.

(12) Tsai, M.-L.; Hadt, R. G.; Vanelderen, P.; Sels, B. F.; Schoonheydt, R. A.; Solomon, E. I. J. Am. Chem. Soc. 2014, 136 (9), 3522-3529.

(13) Kato, M.; Itabashi, K.; Matsumoto, A.; Tsutsumi, K. J. Phys. Chem. B 2003, 107 (8), 1788-1797.

(14) Katada, N.; Kanai, T.; Niwa, M. Microporous Mesoporous Mater. 2004, 75 (1), 61-67.

(15) Korányi, T. I.; Nagy, J. B. J. Phys. Chem. B 2005, 109 (33), 15791-15797.

(16) Dědeček, J.; Wichterlová, B. J. Phys. Chem. B 1999, 103 (9), 1462-1476.

(17) Schlenker, J. L.; Pluth, J. J.; Smith, J. V. Mater. Res. Bull. 1979, 14 (6), 751-758.

(18) Mortier, W. J.; Pluth, J. J.; Smith, J. V. Mater. Res. Bull. 1975, 10

(10), 1037-1045.

(19) Alberti, A. Zeolites 1997, 19 (5), 411-415.

(20) Loewenstein, W. Am. Mineral. 1954, 39 (1-2), 92-96.

(21) Zhao, Z.-J.; Kulkarni, A.; Vilella, L.; Nørskov, J. K.; Studt, F. ACS Catal. 2016, 6 (6), 3760-3766.

(22) Mahyuddin, M. H.; Tanaka, T.; Shiota, Y.; Staykov, A.; Yoshizawa, K. ACS Catal. 2018, 8 (2), 1500-1509.

(23) Delgado, J. A.; Uguina, M. A.; Gómez, J. M.; Ortega, L. Sep. Purif. Technol. 2006, 48 (3), 223-228.

(24) Zhang, Y.; Yu, J.; Yeh, Y.-H.; Gorte, R. J.; Rangarajan, S.; Mavrikakis, M. J. Phys. Chem. C 2015, 119 (52), 28970-28978.

(25) Macedonia, M. D.; Moore, D. D.; Maginn, E. J.; Olken, M. M. Langmuir 2000, 16 (8), 3823-3834.

(26) Smit, B.; Ouden, C. J. J. Phys. Chem. 1988, 92 (26), 71697171

(27) Cheng-chau, C. N. V. G.; Alexander, G.; Armando, B.; Notker,

R. J. Comput. Chem. 2014, 35 (10), 809-819.

(28) Göltl, F.; Hafner, J. J. Chem. Phys. 2011, 134 (6), 64102.

(29) Derouane, E. G. J. Catal. 1986, 100 (2), 541-544.

(30) Derouane, E. G.; Andre, J.-M.; Lucas, A. A. J. Catal. 1988, 110 (1), 58-73.

(31) Derouane, E. G. J. Mol. Catal. A: Chem. 1998, 134 (1), 29-45.

(32) Derouane, E. G.; Nagy, J. B.; Fernandez, C.; Gabelica, Z.; Laurent, E.; Maljean, P. Appl. Catal. 1988, 40, L1-L10.

(33) Wulfers, M. J.; Teketel, S.; Ipek, B.; Lobo, R. F. Chem. Commun. 2015, 51 (21), 4447-4450.

(34) Ipek, B.; Wulfers, M. J.; Kim, H.; Göltl, F.; Hermans, I.; Smith, J. P.; Booksh, K. S.; Brown, C. M.; Lobo, R. F. ACS Catal. 2017, 7 (7), 4291-4303.

(35) Ipek, B.; Lobo, R. F. Chem. Commun. 2016, 52 (91), 1340113404. 